1 Cupps TR, Fauci AS. The vasculitides. In: Smith LH, ed. Major problems in internal medicine, vol 21. Philadelphia: WB Saunders, 1981: 26-49 and 72-87.

2 Gaffey CM, Chun B, Harvey JC Manz HJ. Phenytoininduced systemic granulomatous vasculitis. Arch Pathol induced systemic granulom

3 Lie JT. Disseminated visceral giant cell arteritis. Histopathologic description and differentiation from othe granulomatous vasculitides. Am f Clin Pathol 1978;69: 299-305.

4 Petersen OMF, Frankel SR. Idiopatic granulomatous vasculitis. In Churg A, Churg J, eds. Systemic vasculitides. New York: Igaku-Shoin, 1991;181-91.

5 Hunder GG, Arend WP, Bloch DA, Calabrese LH, Fauci AS, Fries JF, et al. The American College of Rheumatolog 1990 criteria for the classification of vasculitis. Arthritis Rheum 1990;33:1065-144.
6 Berk JE, Cohen M. Granulomas hepaticos. In: Berk JE, ed. Bockus: Gastroenterologia, 4th Spanish edition. Barcelona: Salvat, 1987:3475-90.

7 Mullick FG, McAllister HA, Wagner BM, Fenoglio JJ. Drug related vasculitis. Clinicopathologic correlations in 30 patients. Hum Pathol 1979;10:313-25.

8 Haber MM, Marboe CC, Fenoglio JJ. Vasculitis in drug reactions and serum sickness. In: Churg A, Churg J, eds. Systemic vasculitides. New York: Igaku-Shoin, 1991 : eds. System 13.

9 Bloodworth JMB, Hamwi GJ. Histopathologic lesions as sociated with sulfonylurea administration. Diabetes 1961 10:90-9.

10 Ingelmo $M$, Vivancos J, Bruguera M, Sierra J, Balcells A Angiitis por hipersensibilidad y hepatitis granulomatosa inducida por glibenclamida: a proposito de un caso. Med Clin (Barc) 1980;75:306-8.

\title{
Histological features of the thyroid gland in a patient with lithium induced thyrotoxicosis
}

\author{
Y Mizukami, T Michigishi, A Nonomura, S Nakamura, M Noguchi, E Takazakura
}

\section{Kanazawa \\ University Hospital, Kanazawa, Japan \\ Y Mizukami \\ A Nonomura \\ Department of Nuclear Medicine T Michigishi cytic infiltration. It is postulated that lithium might directly damage thyroid follicular cells and that subsequent re- lease of thyroglobulin into the circulation might be a cause of transient thyro- toxicosis. \\ (f Clin Pathol 1995;48:582-584)}

Department of Internal Medicine

S Nakamura

\section{Department}

of Surgery

M Noguchi

Kurobe Citizens Hospital, Kurobe, Japan: Department of Internal Medicine E Takazakura

Correspondence to: Dr Yuji Mizukami MD Pathology Section, Kanazawa University Hospital,

13-1 Takara-machi, Kanazawa 920, Japan.

Accepted for publication 13 October 1994

\begin{abstract}
A 26 year old woman with lithium induced thyrotoxicosis is reported. The thyrotoxicosis was associated with a nontender diffuse goitre and a low radioiodine uptake by the gland. The thyrotoxicosis was reversible and remitted on withdrawal of the drug. The histopathological alterations of the thyroid glad were characterised by extensive follicular cell disruption with no lympho-
\end{abstract}

Keywords: Thyrotoxicosis, lithium, thyroid histology.

Lithium is increasingly used for the treatment of manic depressive illness. Thyroid disturbances during lithium treatment have been noted. These commonly present as a goitre with or without hypothyroidism ${ }^{1-3}$; more rarely there is a goitre with hyperthyroidism. ${ }^{24-6}$ There have, however, been few reports describing the histological alterations of the thyroid gland during lithium treatment. ${ }^{23578}$

In the present report, we describe the histopathological features of the thyroid gland in a patient with lithium induced thyrotoxicosis which remitted on withdrawal of the drug.

\section{Case report}

A 26 year old woman was referred to us because of a two week history of sweating, palpitations, and anorexia. She had a three year history of manic depressive psychosis and had been taking lithium carbonate, $800 \mathrm{mg} /$ day, for the preceding two years. She had no history of thyroid disease and there was no family history of thyroid disorders. She was clinically euthyroid six months before this episode, and serum values at that time including a thyroxine (T4) of $90 \mathrm{nmol} / 1$ (normal 59-142), a free T4 of $19.6 \mathrm{pmol} / 1$ (normal 9.0-27.0), and a triiodothyronine (T3) of $1.7 \mathrm{nmol} / 1$ (normal 1.2 2.9). Physical examination revealed warm moist hands and fine finger tremor, but exophthalmos was not evident. The thyroid gland was diffusely enlarged and was non-tender. No nodules were palpable. The serum thyroid hormone concentrations were raised: free $\mathrm{T} 4$ $87.5 \mathrm{pmol} / 1$, T3 $3.5 \mathrm{nmol} / 1$, and free T3 $13.6 \mathrm{pmol} / 1$ (normal $3 \cdot 4-8 \cdot 2$ ). TSH was suppressed at $<2.0 \mathrm{mU} / 1$ (normal $<10 \cdot 0$ ). Radioactive iodine uptake was markedly reduced to only $1 \cdot 0 \%$ at 24 hours (normal $10-40 \%$ ). Serum antithyroglobulin and antimicrosome autoantibodies were negative. TSH binding inhibitor immunoglobulin (TBII) was also negative. These clinical and laboratory findings suggested a diagnosis of silent (painless) thyroiditis. Large needle biopsy (Silverman) of both lobes of the thyroid gland was performed. Lithium therapy was stopped and the patient was given propranolol for the control of thyrotoxic symptoms. The values of the serum thyroid hormones continued to rise for two 

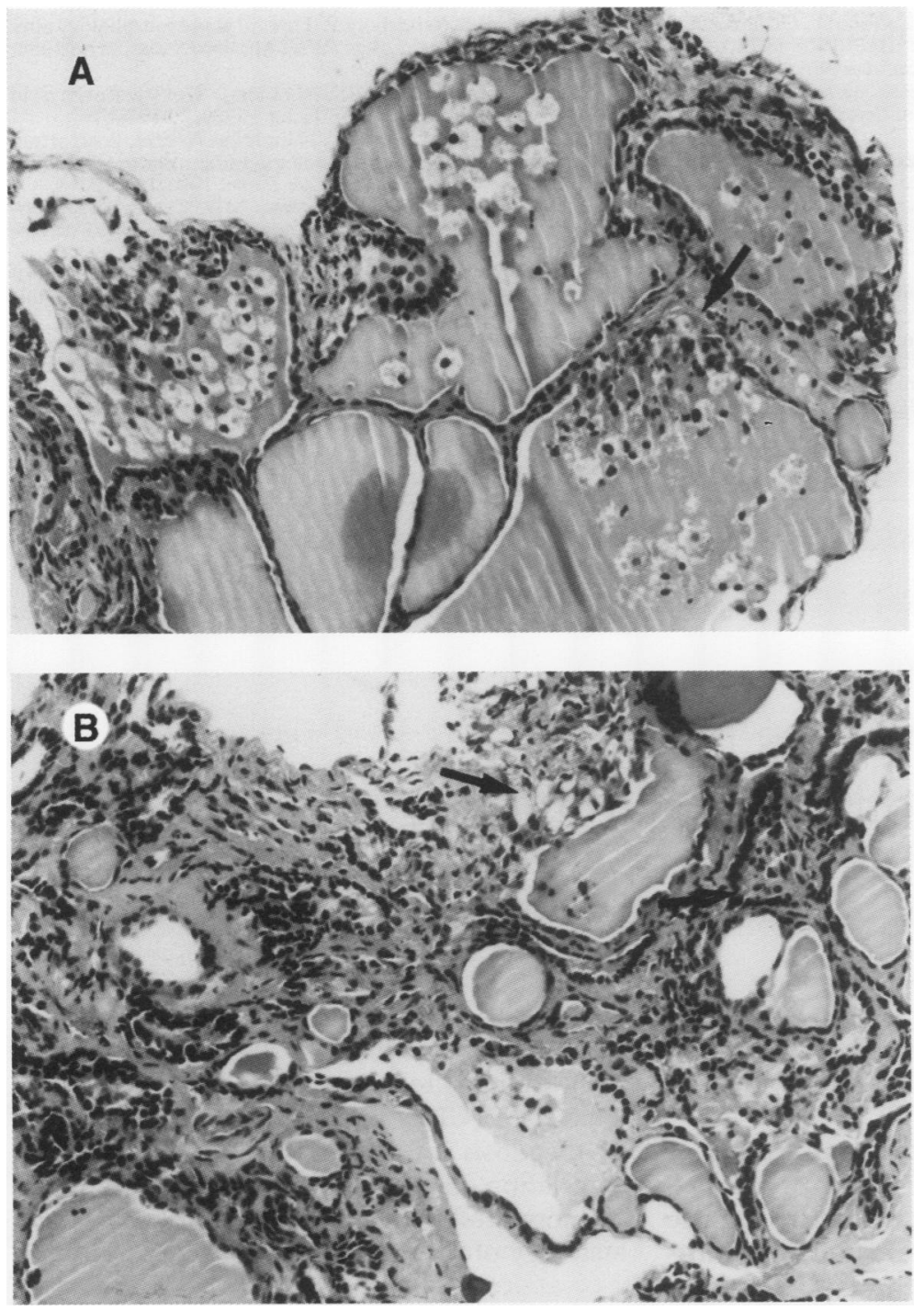

(A) Thyroid follicles are rather distended. Many desquamated follicular cells with vacuolated cytoplasm are present in the colloid of the follicles. Follicular disruption (arrow) is also noted (haematoxylin-eosin). (B) In another focus of the specimen, disrupted follicles (arrows) and rather small atrophied follicles are noted associated with significant stromal fibrosis (haematoxylin-eosin).

weeks and then returned to normal limits. The serum values of thyroid hormones three months after lithium withdrawal were: T4 $92.6 \mathrm{nmol} / 1$, free T4 $21.9 \mathrm{pmol} / 1$, T3 $1.3 \mathrm{nmol} / 1$, and free T3 $6.3 \mathrm{pmol} / \mathrm{l}$. The goitre disappeared and was no longer palpable.

\section{Pathology}

Microscopically the thyroid gland was composed of large distended follicles with abundant colloid. In most of the follicles, follicular lining cells were desquamated, with cytoplasmic vacuolisation (figure). These desquamated follicular cells were present in the follicular colloid, and occasionally thyroid follicles were filled with aggregates of these desquamated follicular cells and macrophages. Some follicles were disrupted, and at the points of disruption there was minimal lymphocytic infiltration. In another focus, a considerable amount of stromal fibrosis was noted in close association with follicular disruption and rather small atrophied follicles (figure). Lymphocytic infiltration, suggesting the presence of chronic thyroiditis, was not evident anywhere in the specimen.

\section{Discussion}

The mechanism of action of lithium on the biosynthesis of thyroid hormone has not been elucidated completely, but the drug has been shown to inhibit iodine uptake into the thyroid gland, impair coupling of iodotyrosines, and interfere with the release of hormone from the gland. ${ }^{9}$ Considering the suppressive effects of lithium on thyroid function, the occurrence of lithium induced thyrotoxicosis is surprising, and the causal mechanisms are still uncertain.

The present case was characterised by hyperthyroidism which remitted on cessation of the lithium treatment, by goitre with no tenderness, and by low radioactive iodine uptake by the gland. Histologically the thyroid gland showed a marked follicular disruption. These clinical, laboratory, and histological features resembled those found in patients with silent thyroiditis or postpartum thyroiditis, which are considered to represent a destructive phase of chronic thyroiditis and to be due to enhancement of autoimmunity. ${ }^{10}$ In the present case, however, circulating autoantibodies for thyroid antigens were negative and chronic thyroiditis was not evident histologically. Lithium itself may directly injure thyroid follicular cells and cause thyroid follicular destruction. ${ }^{8}$ Subsequent release of thyroglobulin increases the serum thyroid hormone concentration, causing hyperthyroidism and low radioactive iodine uptake by the gland. Such a follicular destruction has also been reported in amiodarone induced hyperthyroidism. ${ }^{11}$ Follicular disruption may also occur in association with physical examination (palpation) or surgical procedures of the thyroid gland. ${ }^{12}$ In our experience of more than 2000 large needle biopsies of the thyroid gland, we were unable to find such non-specific follicular disruption in a single case. ${ }^{13}$ The histological changes found in the present case are thus unlikely to have been caused by the needle biopsy procedure. In addition, the patient had no history of trauma to the neck preceding the episode.

To date, eight cases of lithium induced thyrotoxicosis have been reported. ${ }^{24-6}$ Three of the four patients with lithium associated thyrotoxicosis reported by Brownlie et $a l^{2}$ had a past history of thyroid diseases, including Graves' disease. These four patients were treated with antithyroid drugs and radioiodine. On the other hand, Rosser ${ }^{4}$ and Reus et $a l^{6}$ each reported one patient who became euthyroid spontaneously with cessation of lithium treatment. Radioactive iodine uptake was not increased in either case, and the clinical laboratory findings suggested a causal relationship between the transient thyrotoxicosis and follicular destruction, although histological examination of the thyroid gland was not performed in either case.

Although histological examination of the thyroid gland in patients with lithium induced thyrotoxicosis has rarely been performed, the present study suggests that lithium causes direct damage to the thyroid follicles and that the follicular disruption contributes to the transient thyrotoxicosis. 
1 Schou M, Amdisen A, Jensen SE, Olsen T. Occurrence of goitre during lithium treatment. $B M F$ 1968;iii:710-3.

2 Brownlie BEW, Chambers ST, Sandler WA, Donald RA. Lithium associated thyroid disease - a report of 14 cases Lithium associated thyroid disease - a report of 14 cases
of hypothyroidism and 4 cases of thyrotoxicosis. Aust NZ

3 Lindstedt G, Nilsson LA, Walinder J, Skott A, Ohman R. On the prevalence, diagnosis and management of lithiuminduced hypothyroidism in psychiatric patients. $B r f P s y-$ chiatry 1977;130:452-8.

4 Rosser R. Thyrotoxicosis and lithium. Br f Psychiatry 1976; 128:61-6.

5 Franklin LM. Thyrotoxicosis developing during lithium treatment: case report. NZ Med f 1974;79:782.

6 Reus VI, Gold P, Post R. Lithium-induced thyrotoxicosis. Am $\mathcal{f}$ Psychiatry 1979;136:724-5.

7 Kontozoglou T Mambo N. The histopathologic features of lithium-associated thyroiditis. Hum Pathol 1983;14:737-9.
8 Fauerholdt L, Vendsborg P. Thyroid gland morphology after lithium treatment. Acta Pathol Microbiol Scand Sect A 1981; 89:339-41.

9 Berens SC, Bernstein RS, Robbins J, Wolff J. Antithyroid effects of lithium. $₹$ Clin Invest 1970;49:1357-67.

10 Mizukami Y, Michigishi T, Nonomura A, et al. Postpartum thyroiditis - a clinical, histologic and immunopathological thyroiditis - a clinical, histologic and immunopathological

11 Smyrk TC, Goellner JR, Brennan MD, Carney JA. Pathology of the thyroid in amiodarone-associated thyrotoxicosis. Am $₹$ Surg Pathol 1987;11:197-204.

12 Carney JA, Moore SB, Nothcatt RC, Woolner LB, Stillwel GK. Palpation thyroiditis (multifocal granulomatous folliculitis). Am ₹ Clin Pathol 1975;64:639-47.

13 Mizukami Y, Michigishi T, Nonomura A, Nakamura S, Ishizaki $T$. Pathology of chronic thyroiditis: A new clinically relevant classification. Pathol Annu 1994;29: 135-58.

\title{
Splenic lymphoma with circulating villous lymphocytes
}

\author{
F Imbing Jr, D Kumar, S Kumar, G Yuoh, F Gardner
}

\begin{abstract}
This report describes the occurrence of splenic lymphoma with villous lymphocytes (SLVL) in a 56 year old white female with a family history of chronic lymphocytic leukaemia. Other unusual features included a marked lymphocytosis with counts up to $224 \times 10^{9} / 1$ and marked clumping of lymphocytes in EDTA anticoagulated blood. The neoplastic cells were $\mathrm{CD} 19+, \mathrm{CD20}+, \mathrm{CD22}+, \mathrm{CD22}+$, $\operatorname{IgM}+, \lambda+, \kappa-, \operatorname{CD5}-$, and CD10-. The spleen had nodular infiltrates of $B$ lymphocytes in the region of the white pulp with minimal red pulp involvement. Electron microscopy of peripheral blood lymphocytes revealed cells with polar cytoplasmic processes. This report underlines the need for detailed analysis, including morphology and immunophenotyping, for each patient with a small B cell lymphoproliferative disorder

(f Clin Pathol 1995;48:584-587)
\end{abstract}

Pathology, The University of Texas Medical Branch, Texas, USA F Imbing Jr

D Kumar

$S$ Kumar

G Yuoh

Department of Internal Medicine F Gardner

Correspondence to: Dr D Kumar Department of Pathology, Division of Anatomical Pathology, 22 South Greene Street, Baltimore MD 21201-1595, USA.

Accepted for publication 13 October 1994
Keywords: Splenic lymphoma with villous lymphocytes, immunophenotype, familial, electron microscopy.

The disease now referred to as splenic lymphoma with villous lymphocytes (SLVL) ${ }^{1}$ was previously described by Neiman et $a l^{2}$ under the rubric malignant lymphoma simulating leukaemic reticuloendotheliosis. In their study of 10 cases, Neiman et al compared and contrasted this disorder with hairy cell leukaemia (HCL) and prolymphocytic leukaemia (PLL) and emphasised the importance of a histological examination of the spleen in making the distinction. The patient described here was ini- tially thought to have B chronic lymphocytic leukaemia (CLL) based on her family history. A diagnosis of SLVL was later made by correlating the morphology and immunophenotype of peripheral blood lymphocytes and histology of the resected spleen.

\section{Case report}

A 56 year old white female presented with progressively increasing abdominal girth in November 1993. On physical examination, the spleen was massively enlarged, being palpable $13 \mathrm{~cm}$ below the left costal margin. There was no peripheral lymphadenopathy. Abdominal computed tomography scans confirmed massive splenomegaly with hypodense areas suggestive of leukaemic or lymphomatous infiltrate, or both. No mediastinal or abdominal lymphadenopathy was observed.

Examination of the peripheral blood revealed a haemoglobin concentration of $104 \mathrm{~g} / 1$; a platelet count of $121 \times 10^{9} / 1$; a white blood cell count (WBC) of $69 \times 10^{9} / 1$, with $98 \%$ lymphocytes. The lymphocytes were larger than small lymphocytes and had a moderate amount of cytoplasm. The nuclei were round, with few clefted and irregular forms and had a clumped chromatin pattern (fig 1). Small but distinct nucleoli were present in some of the cells. Irregularly distributed surface projections, which were sometimes concentrated at one or both poles of the cell, were seen in some cells. An unusual feature noticed in the smears was marked clumping of the lymphocytes (fig 1). The leukaemic cells were tartrate resistant acid phosphatase (TRAP) negative. Electron microscopic studies were carried out on buffy coated preparations of peripheral blood. Small villous 